\author{
TOMASZ GAŁKOWSKI \\ University of Cardinal Stefan Wyszyński, Warsaw, Poland \\ (D) https://orcid.org/0000-0001-9166-9516
}

\title{
Migration in the Human Rights Context
}

\begin{abstract}
The phenomenon of migration concerns 3.3\% of the general population living in the world and its number is still increasing. In order to stop migration measures are taken, which are largely against human rights to migration. The right to migration itself is denied. The activities that aim to restrict the right and not to regulate it become an alarming tendency. As a category of mixed rights, whose title is in the human nature (dignity), measure is positive regulation of exercising these rights as its internal element.
\end{abstract}

Keywords: migration, human rights, mixed rights, regulations, solidarity

Population movements have been and still are a common phenomenon, from the great migrations of nations to today's migration phenomena. On the basis of numerous publications, one can asses the scale of the modern migration phenomenon. According to the UN data from 2018, migration phenomenon concerns 244 million people living outside their country of birth, which constitutes $3.3 \%$ of the general population living in the world. ${ }^{1}$ During the last five years this number has increased by 12 million. It can be forecasted that this trend will be constantly growing, an example of which are the attempts to limit it. On the one hand, the right to migration contained in the Universal Declaration of Human Rights is emphasised, but on the other hand, present efforts to limit it are, at the first evaluation attempt, somewhat inconsistent with this right. An example of such activity is a communication issued by the European Council after the meeting on 23 April 2015 concerning the incident on

${ }^{1}$ United Nation: World Migration Report 2018, https://www.iom.int/wmr/chapter-2 (accessed: 16.04.2019). 
the Mediterranean Sea, when a ship transporting hundreds of African emigrants from Libia to Europe sank. In the communication one can read that "[T]he European Union will mobilise all efforts at its disposal to prevent further loss of life at sea and to tackle the root causes of the human emergency that we face, in cooperation with the countries of origin and transit." Despite these declarations, from the remainder of the communication it can be inferred that the planned initiatives aim to stop the phenomenon of migration from Africa to Europe by taking certain steps, such as fighting the phenomenon of people smuggling, destroying the ships used by smugglers, or taking actions resulting from joint security and protection policy of the European Union. The goal of the above proposals is to prevent illegal migration flows. What is understood by illegal? The position of the European Council, presented here as one of the examples of attempts to solve today's migration problem, indicates internal contradictions in the system of human rights' protection. On the one hand, the human right to migration is acknowledged and considered undeniable, but on the other illegality of migration is indicated and eventually steps to limit the phenomenon and the right itself are taken. Illegality concerns unlawful activity. To show illegality of such an activity one should first define the scope of the right to migration in the context of human rights, and next draw attention to defining individuals who are entitled to exercise this right.

In today's discussion concernig the phenomenon of migration, and especially accepting refugees by some European countries and attempts to solve this problem, there are voices stating clearly that migration is not a human right, as was said in April 2018 by the Hungarian minister of foreign affairs Péter Szijjártó before the debate on "migration pact" in New York. In response to statements that migration is right and should be accepted, he expressed his country's position that migration is dangerous. This statement made in the context of care for the safety and sovereignty of Hungary is contradicted by the imposed necessity to accept illegal migrants. However, in the minister's utterance one can notice that his opinion concerns the phenomenon of illegal migration, which does not prevent him from making a general statement that the right to migration is not a fundamental human right. The aim of countries should be stopping and not supporting migration. ${ }^{3}$

2 Special meeting of the European Council, 23 April 2015 - statement, https:// www.consilium.europa.eu/en/press/press-releases/2015/04/23/special-euco-statement/ (accessed: 16.04.2019).

3 “ONZ naraża świat. Migracja niebezpieczeństwem, a nie prawem," https:// www.tvp.info/36363951/onz-naraza-swiat-migracja-niebezpieczenstwem-a-nie-prawem (accessed: 16.04.2019). 
During the summit in Marrakesh $164 \mathrm{UN}$ member states, in the face of final opposition of about 30 countries, signed the GCM agreement (Global Compact for Safe, Orderly and Regular Migration), commonly referred to as "migration pact," which confirmed that migration is a human right. The pact concerned setting international standard procedures and facilitating international migration-related cooperation. ${ }^{4}$ The document is not legally binding, but one can expect that its acknowledgement by so many countries will cause pressure to apply it. Resistance and reluctance to accept this document at the session of the General Assembly of the United Nations, as reported by the Polish Government Information Center, resulted from the right to protect one's own sovereignty and to decide what can be accepted within the state, as well as lack of clear definition and differentiation between legal and illegal migration. From the perspective of the Polish government, the issues concerning the attempts to solve the problem of migration should aim at defining illegality of the phenomenon, that is establishing clear norms, trespassing of which would allow to stop migration process.

Looking at the contemporary discussion on the right to migration one can notice that it is inspired by the current problems connected with the flow of population from Asia and Africa to Europe or the USA. Actually, it is not a discussion about the right to migration but about the necessity to differentiate legal migration from illegal one. It is difficult to determine, though, whether the decision to clearly define these two phenomena will cause a change in approach of the countries which now refuse to accept immigrants. They do not try to enable "legal," in their opinion, migrants to reside within the territory of their own country. Therefore, is defining legality or illegality of a migrant an element facilitating implementation of the right to migration?

\section{From migrants' rights to the right to migration}

The rights that migrants are entitled to confirm the earlier fact of migration. They are the consequence of the expressed right to migration. There is some co-dependence between them, because migration motives and defining the boundaries of its "legality" determine the legal status of the migrant at the moment of his or her crossing the border of another country and staying on its territory.

${ }^{4}$ M. StrZaŁKowski: "Pakt migracyjny ONZ przyjęty," https://www.euractiv.pl/section/migracje/news/pakt-migracyjny-onz-przyjety/ (accessed: 16.04.2019). 
The situation and legal status of migrants changed when the right to migration as a human right was announced. Before this, the rights of people residing outside their own country were protected as rights of foreigners, as long as their country of origin had the possibility of protection and wanted to do it also on its own territory. It resulted from the reciprocity rule (do ut des) based on the interest of the state, according to which a migrant should be protected on the territory of a given country, as long as the same right and to a similar extent was guaranteed by the country of their origin. International norms did not impose an obligation to accept strangers in one's own state territory. Countries were free to decide which people could reside on its territory, subject to the earlier adopted inter-state agreements and obligations. To a large extent, accepting foreigners was based on the evaluation of their usefulness for the receiving country. ${ }^{5}$ The capital and commercial factors fostered and encouraged emigration. It is believed that the same factors extensively contributed to the growth of population migration at the beginning of this century. In the face of numerous objections, these factors and not the human right to migration accelerated and fostered the migration phenomenon. ${ }^{6}$ Acceptance and permission to stay in a new country resulted in the acquisition of legal rights which exist in it (e.g. acknowledgment of legal personality, civil and political rights). It was the receiving country that was accountable for the legal protection of people having rights given by the state.

Together with the declaration of the human right to migration, ${ }^{7}$ the attitude to the motives of accepting immigrants and defining their rights has changed, at least in its assumptions if not in reality. The current relationship based on nationality, typical of the reciprocity rule, is being replaced with the common requirement of protection of a human being as a subject who is entitled to basic rights by virtue of his personal dignity. Human rights as a result of certain necessity provoked by human solidarity, and in case of the right to migration the situation of solidarity and concern about the lives of people after World War II, have become a catchy idea to express the right to migation and migrants' rights. However, in case of particular solutions provoked by unexpectedly occurring situations, the idea is experienced and appreciated in the era of globalisation - cosmopolitan solidarity from the stoic point of view ${ }^{8}$ is not fully

${ }^{5}$ A. CAssese: I diritti umani nel mondo contemporaneo. Roma-Bari 2000, pp. 86, 89-90.

${ }^{6}$ S. BIN: "Migrare è un diritto. Ma per tutti?," https://www.unimondo.org/Notizie/ Migrare-e-un-diritto.-Ma-per-tutti-160385 (accessed: 16.04.2019).

7 Universal Declaration of Human Rights, Article 13.

${ }^{8}$ R. Sobański: “Prawo jako wartość.” Prawo Kanoniczne42, nos. 3-4 (1999), p. 19. 
reflected in facts. In everyday situations there occur meetings and necessity to make decisions not in reference to ideas but particular people, whose rights are respected regardless of where they come from. Humanity contained in the category of human rights is not a result of collectivisation or solidarity but becomes tangible in the one whose personal dignity constitutes the foundation of available and acknowledged rights.

The idea of the right to migration faced specific obstacles and clashed with other rights and interests of states which, unlike in the past, concern the capital and market area connected with the economic development and affluence of the state. More and more frequently, safety reasons or even loss of civilisational, cultural, and above all national identity lead to protecting and closing the borders to the arriving immigrants. In such situations, the state justifies its stance referring to the right to protect its own territory from violation by other countries, to control and protect its own borders. Crossing country borders is a characteristic element of migration. It is the reason why border control plays a major role in all kinds of discussions and arguments about the phenomenon of migration. International law guarantees stability of state borders, which is the condition of peaceful coexistence of countries and nations. It is the erga omnes right of the country. As a consequence, it also protects its own right to control those who are leaving it but also those who want to cross its borders. The category of what is inside and outside determines not so much the attitudes to the phenomenon of migration as above all to particular persons. It is not a common phenomenon of migration that is a problem but a particular person who is at the border of a country. This "methodological nationalism," to use the term coined by Ulrich Beck, which clearly differentiates between what is inside and outside, reduces the state's attitude to a migrant to the category of clearly defined political affiliation. ${ }^{9}$ It leaves aside a serious doubt about the actual shift from the category of reciprocity in migration matters, based on the relationship of nationality to the actual protection of a human being in case of his or her migration. It seems that the status of a citizen, who is entitled to full protection, outweighs the status of a human being demanding the same protection. The argument for the accomplished change is the fact of accepting the right to immigration and the rights of an immigrant coming from another country, regardless of the same situation of this very country's own citizens residing in the territory of a foreign country. Reciprocity was replaced by the category of the human right, which in turn results in at least the appearance of reciprocity.

${ }^{9}$ U. BecK: Władza i przeciwwładza $w$ epoce globalnej. Nowa ekonomia polityki światowej. Warszawa 2005, p. 83. 
Particular situations forced a revision of grandiloquent phrasing. The right to migration, in order to be something that really exists not just in the domain of desires and declarations but as thing that a human being is entitled to and can freely enjoy, requires a precise subjective and objective specification as along with determining the breadth of this term. Making this right precise can be regarded as an expression of human solidarity. Solidarity can exist without law but "no legal community cannot afford not to be based on solidarity." 10 However, this statement reqires an assumption that there will be an agreement on the rightness of the legal regulation. In order for law to fulfil its role and be effective, first people's beliefs have to converge in the mutual will to survive and coexist peacefully.

\section{The right to migration}

Human right to external migration was defined in Article 13 of the Universal Declaration of Human Rights. ${ }^{11}$ From the formulation of the right results the possibility to choose (the right to the freedom of choice) the place of residence and to move within the borders of one's state, as well as the right to leave any country, including one's own and to return to it. As it results from the character of each declaration, its content is not binding but constitutes the foundation for the legal rules of international law and as such becomes binding for all its subjects. The right to move freely was confirmed by the International Covenant on Civil and Political Rights in Article 12. It is implied by the above documents, though their interpretation allows different interpretations, that at least the right to freedom of movement is by principle a basic right as it is part of the right to live and settle down within a "common home," which is the area of the Earth. As human rights, that is common, inherent, inalienable, inviolable and indivisible, they should be enjoyed by everybody residing in the territory of a given country. One can assume that countries respecting human rights should in equal measure respect migrants' rights. Countries that do not respect human rights should not be expected to give advantageous position to migrants' rights with regard to other rights exercised

${ }^{10}$ R. Sobański: "Prawo jako wartość...," p. 19.

11 Article 13.1: "Everyone has the right to freedom of movement and residence within the borders of each state"; 13: "Everyone has the right to leave any country, including his own, and to return to his country." 
by a human. However, the phenomenon of migration from the beginning of the 20th century illustrates that even in the countries which take pride in their protection and promotion, migrants are not treated accordingly with their rights and do not enjoy solidarity equally to the other society members. ${ }^{12}$

According to the principles expressed in the above quoted documents, the right to migration as a form of exercising the guaranteed liberties should be exercised by all people, excluding any form of discrimination on grounds of national or social origin, sex, race, colour of skin, religion, citizenship, affiliation with social groups, or political beliefs. ${ }^{13} \mathrm{~A}$ migrant can be any person who decides to leave his or her country or foreign place of residence. The concept of migrant includes different categories of people whose common element is leaving one's place of residence in order to stay temporarily or permamently in another country. It concerns both people who make the decision to move (resettle) of their own free will and those who were forced to do it. Therefore, one should differentiate migration from other forms of population movements, which are not connected with the intention of temporary or permanent settlement in the territory of a foreign country. Thus, migration phenomenon is determined by the motives it is induced by. They also determine the legal status of a migrant residing in a foreign country.

In international law, "migration" does not exist as a general legal category. This term is used in different sectors of international law, depending on specific ways which are the reason for undertaking it. Migration is dependent on the economic, social, political context as well as legal culture in which the migration phenomenon is recognised, which is indicated by different international documents concerning particular categories of migrants: asylum seekers or refugees, displaced persons, economic migrants, the so-called environmentally displaced persons (environmental migrants). ${ }^{14}$

Additionally, irrespective of reasons which force the migration phenomenon, the right to migration should include all the possible conditions, which allow taking advantage of this right. They include, for instance, obtaining relevant documents allowing movement, leaving the country of residence and entering a foreign country. Lack of possibility to have such documents or their revocation is considered to be a violation

12 A. PopŁawska: “Migracje a prawa człowieka w kontekście stosunków międzynarodowych." Kultura i Polityka 17 (2015), p. 89.

${ }^{13}$ Convention for the Protection of Human Rights and Fundamental Freedoms, Article 14.

${ }^{14}$ S. Trevisanut: "Immigrazione (dir. int.)." In: Treccani. Diritto on line, http://www. treccani.it/enciclopedia/immigrazione-dir-int_(Diritto-on-line)/ (accessed. 17.04.2019). 
of the right to leave the place of residence. All the restrictions connected with the so-called selective and exclusive migration policy, bureaucratic provisions about receiving documents allowing departure or arrival (visas, residence permits) are against this right. Processes connected with receiving the documents instead of enabling people to exercise the right to migration often illustrate some form of its restriction. ${ }^{15}$

\section{Illegal migration}

The right to external emigration, as confirmed by the history of the migration phenomenon, is not always advantageous from the point of view of the country which is the aim of migration. One of the fundamental functions of the state is securing its borders, which is the consequence of care about the security of the country and its citizens. The necessity to control the borders and flow of population is connected with it. However, countries should not limit the freedom to leave their territory by those who reside on it as its citizens or immigrants.

The right to leave and reside in the territory of a foreign country cannot be derived from the right to migration, although it might seem to be its consequence. Such a right is not guaranteed. A country does not have the duty to accept others on its territory as well. It is against the fundamental function of the country to guard its borders and safety of its citizens as a consequence of its sovereignty. It was confirmed in the International Covenant on Civil and Political Rights, according to which the right to leave any country, including one's own, "shall not be subject to any restrictions except those which are provided by law, are necessary to protect national security, public order (ordre public), public health or morals or the rights and freedoms of others, and are consistent with the other rights recognized in the present Covenant." 16 These restrictions do not concern those who want to come to their own country. ${ }^{17}$

According to the above regulations of the Covenant, limitations concern the freedom of movement and the freeedom to choose a place of residence of a person remaining on the territory of any country, as

15 S. Bin: "Migrare è un diritto. Ma per tutti?"

16 Article 12.3.

17 Universal Declaration of Human Rights, Article 13.1: Everyone has the right to freedom of movement and residence within the borders of each state. International Covenant on Civil and Political Rights, Article 12.4: No one shall be arbitrarily deprived of the right to enter his own country. 
long as this residence is legal, and the possibility to leave it. ${ }^{18}$ Nothing is said, though, about restrictions concerning the possibility to enter the country as clearly as in the case of the freedom to move or leave. However, such a possibility is not excluded. Article 12.3 mentions conditions necessitating the restrictions which determine the stable functioning of a country and thus affect risk assessment also from the arriving people. However, in case of people seeking to be accepted in the territory of a given country the circumstances mentioned in the Covenant might actualised on the basis of assumptions or probablilities. In case of residing or leaving the above circumstances can be verified. It is very difficult to assume that the risk posed by the citizen of a given country in its territory will be the argument justifying full permission for his or her departure and similar behaviour in the territory of a foreign country. The state has other legal means aiming to curb the illegal activity of its citizen rather than condemning him to "wilful banishment." Nevertheless, the statement contained in Article 12.3 of the Covenant is significant for the global state solidarity, which can be secured by restricting free exercise of the right to migration, including the right to leave one's own country.

Regulations concerning restrictions of free migration contained in Article 13 of the Covenant are not limitless. They cannot be used arbitrarily. Therefore, the Covenant provides stable forms of legal regulations which can be executed only under legislation, thus excluding other normative acts. Some arbitrariness may occur in the assessment of the range of circumstances allowing the introduction of restrictions. Together with the above-mentioned predictions concerning the probablity of occurence of incidents specified in Article 12.3, they require verifiable assessment, and in my opinion, individual approach to every person applying for their right to migration. It is a human right, and a right of a particular person. As they are entitled to a commonly recognised right, they are in a situation described in legal regulations. It would help to secure the right to migration if the state cooperated with the social environment, which in the country opening its borders, is rooted in it and is an immigrant's own environment. ${ }^{19}$

An additional form of protecting migrant's rights in the territory of a foreign country is the prohibition of expulsion of people having asylum or refugee status, regulated by appropriate provisions of international law. In relation to people not having asylum or refugee status the ban to return people applying to reside on the territory of a foreign country (the princi-

18 Articles 12.1 and 12.2 .

${ }^{19}$ A. PopŁawsKa: "Migracje a prawa człowieka...," pp. 93-94. 
ple of non-refoulement) applies with regard to expulsion countries of the so called increased risk, on the area of which the expelled person can be extradited or returned.20

Determining whether illegal migration (emigration and immigration) can exist concerns establishing precise conditions which verify generally formulated legal norms restricting the freedom to exercise the right to migration. Legal norms do not allow arbitrary decisions, but because of their general and abstract character are exposed to interpretation ambiguity and thus the possibility to be applied in the way that suits the people making decisions about migrants. Legality or illegality of migration should be judged depending on the definition and status of the migrating person to whom these norms refer.

\section{A few conclusions}

1. The right to migration includes a wide range of behaviours connected with free movement within one's country of origin or outside it. It also concerns the possibility to reside permanently or temporarily in the territory of a foreign country. However, such a possibility is not a human right and is regulated by appropriate legal norms. Normative restrictions result from the state's right to self-determination within its borders and are an expression of its autonomy and sovereignty.

2. The person's right to migration is specifically expressed in the definition of the migrant's status. It determines, having at the same time the possibility to restrict, the rights he or she is particularly entitled to. On the one hand, these restrictions protect the state, but on the other enable a person to exercise their basic right to migrate. They are restrictions for the state itself, preventing it from making arbitrary decisions.

3. The right to migrate, due to the fact that it can be limited, belongs to the category of mixed rights, whose title has natural foundation (the right to free movement), but the measure is positive. ${ }^{21}$ The change of terminology in defining its range would be more appropriate and corresponding with the right to migration, since what matters is regulating the migration phenomenon and not restricting the right. Positivity of the

${ }^{20}$ O. ŁaCHACZ: “Zasada non-refoulement w międzynarodowym prawie uchodźczym — zwyczaj międzynarodowy czy też peremptoryjna norma prawa międzynarodowego?" Problemy Współczesnego Prawa Międzynarodowego, Europejskiego i Porównawczego 15 (2017), pp. 134-142.

${ }^{21}$ J. Hervada: Introduzione critica al diritto naturale. Milano 1990, pp. 72-73. 
right's measure results from the right to migration and the state's right to self-determination.

4. The right to migration cannot be confined in one of theoretical legal categories, in line with the commonly accepted categorisation developed by Czech-French lawyer Karel Vasak at the end of 1970s. ${ }^{22}$ The right to migration does not concern only the freedom to move, but at its foundation lies the right to life and choice of possibly the best conditions which will foster it and contribute to to the development of decent individual and social (most often family) life. Thus, liberties are connected with the category of social rights (economic, social, cultural), that is those requirements whose fulfilment a social group can demand from a community in order to secure a decent life for themselves. ${ }^{23}$ Social rights are an expression of migrant's legal status, they are migrant's rights. However, they are related with the right to migration because the opportunity to live a decent life is intertwined with the assessment of the possibility of its realisation in a given country. These conditions greatly influence the choice of a country which is the destination of migration. Due to legal regulations protecting migrants, the right to migration can be placed in the category of solidarity rights (rights to peace, environment, development), which serve a person, his o her certain goods and values and require supportive cooperation of the whole society, or at least the one which shares these goods and values.

5. The right to migration can remain merely a slogan referring to human solidarity. In its deeper meaning, though, it can contribute to developing and strengthening this solidarity as long as it takes the measure of its own range.

\section{Bibliography}

Becк U.: Władza i przeciwwładza w epoce globalnej. Nowa ekonomia polityki światowej. Warszawa 2005.

BIN S.: “Migrare è un diritto. Ma per tutti?," https://www.unimondo.org/Notizie/Migrare-e-un-diritto.-Ma-per-tutti-160385 (accessed: 16.04.2019).

CAssese A.: I diritti umani nel mondo contemporaneo. Roma-Bari 2000.

${ }^{22}$ A. KobYLiński: “ 'Nowe prawa człowieka' a czysta teoria prawa Hansa Kelsena.”

In: O prawach człowieka nieco inaczej. Eds. R. Moń, A. KoвYLIŃski. Warszawa 2011, p. 231.

${ }^{23}$ Н. Sковоwsкi: Problematyka praw człowieka. Warszawa 1996, p. 27. 
Convention for the Protection of Human Rights and Fundamental Freedoms, https://www.echr.coe.int/Documents/Convention_ENG.pdf\%23page=9 (accessed: 17.04.2019).

European Council: Special meeting of the European Council, 23 April 2015 - statement, https://www.consilium.europa.eu/en/press/press-releases/2015/04/23/ special-euco-statement/ (accessed. 16.04.2019).

Hervada J.: Introduzione critica al diritto naturale. Milano 1990.

International Covenant on Civil and Political Rights, https://www.ohchr.org/en/ professionalinterest/pages/ccpr.aspx (accessed 17.04.2019).

KobYLiński A.: “'Nowe prawa człowieka' a czysta teoria prawa Hansa Kelsena.” In: O prawach człowieka nieco inaczej. Eds. R. Moń, A. KobylińsKi. Warszawa 2011, p. 231-247.

ŁACHACZ O.: “Zasada non-refoulement w międzynarodowym prawie uchodźczym - zwyczaj międzynarodowy czy też peremptoryjna norma prawa międzynarodowego?" Problemy Współczesnego Prawa Międzynarodowego, Europejskiego i Porównawczego 15 (2017), pp. 134-142.

“ONZ naraża świat. Migracja niebezpieczeństwem, a nie prawem,” https://www. tvp.info/36363951/onz-naraza-swiat-migracja-niebezpieczenstwem-a-nieprawem (accessed: 16.04.2019).

PopŁawska A.: "Migracje a prawa człowieka w kontekście stosunków międzynarodowych.” Kultura i Polityka 17 (2015), pp. 84-96.

H. SKorowski: Problematyka praw człowieka. Warszawa 1996.

STRZAŁKOwsкi M.: "Pakt migracyjny ONZ przyjęty,” https://www.euractiv.pl/section/migracje/news/pakt-migracyjny-onz-przyjety/ (accessed: 16.04.2019).

Sobański R.: "Prawo jako wartość." Prawo Kanoniczne 42, nos. 3-4 (1999), pp. $11-26$.

Trevisanut S.: “Immigrazione (dir. int.)." In: Treccani. Diritto on line, http:// www.treccani.it/enciclopedia/immigrazione-dir-int_(Diritto-on-line)/ (accessed 17.04.2019).

United Nation: World Migration Report 2018, https://www.iom.int/wmr/chapter-2 (accessed: 16.04.2019).

Universal Declaration of Human Rights, https://www.un.org/en/universal-declaration-human-rights/ (accessed: 18.04.2019).

ToMasz GaŁKowsKI

La migration dans le contexte des droits de l'homme

Résumé

Le phénomène de migration concerne 3,3\% de la population vivant dans le monde et son nombre ne cesse de croître. Afin d'arrêter la migration, des mesures sont prises, toutefois elles sont largement opposées au droit humain de migrer. Ce droit, lui-même, est également nié. Des actions visant à limiter réellement la loi, et non à la réglementer 
s'avèrent un phénomène perturbateur. En tant que catégorie de droits mixtes, lesquels sont de nature humaine (dignité), la mesure devient la régulation positive de l'exercice des droits en tant que leur élément interne.

Mots clés : migration, droits humains, droits mixtes, réglementation, solidarité

TOMASZ GAŁKOWSKI

\title{
Migrazione nel contesto dei diritti dell'uomo
}

\begin{abstract}
Il fenomeno della migrazione concerne il 3,3\% della popolazione che vive nel mondo e quel numero continua a crescere. Per fermare la migrazione vengono adottate varie misure, nella maggior parte contrarie al diritto umano di migrare. Perfino questo stesso diritto in sé è negato. Le azioni per limitare effettivamente la legge, non per regolamentarla, si stanno rivelando dirompenti. In quanto categoria di diritti misti, intrinseci alla stessa natura umana (dignità), la misura diventa regolazione positiva dell'esercizio dei diritti come il loro elemento interno.
\end{abstract}

Parole chiave: migrazione, diritti umani, diritti misti, regolamentazione, solidarietà 